\title{
Replevin: A Public Archivist's
}

\section{Perspective}

\begin{abstract}
This article suggests that the times are not propitious for measures that would sanction the removal of public documents from public control, that the integrity - or completeness - of a body of records is a fundamental principle of the archival profession, that nothing should be done that would even seem to condone or encourage the theft of records, and that the $\mathrm{Na}$ tional Archives, at least, would be disinclined to seek the return of alienated records that are publicly accessible and professionally preserved.
\end{abstract}

$\mathbf{R}$ EPLEVIN WAS one of those remarkable contrivances of England's medieval court system, a writ that enabled subjects to gain access to the king's court in their search for justice. Armed with a writ of replevin, the subjects could, in effect, ask the court to return to them personal property that had been wrongfully taken and detained, or wrongfully held in custody by another person, and could obtain damages for their temporary loss of the property.

In our own day the term has taken on a more general meaning-the recovery of alienated personal property through a legal proceeding, usually modern rules of civil procedure rather than a writ. It is still primarily used by private parties. ${ }^{1}$ However, when the property involved consists of manuscripts with significant historical or monetary value, and certainly when such an action is brought by a government, replevin can become a matter of concern for librarians and archivists.

Twenty-odd years ago the discovery of field notes of the Lewis and Clark expedition and the subsequent litigation over their ownership disturbed the otherwise calm relations among those who work with rare or

James E. O'Neill is the deputy archivist of the United States. His article is based on a paper presented on June 25, 1978, in a session on replevin at the Annual Conference of the American Library Association in Chicago. unique documents. In that instance the court ultimately decided against the government's claim, and the notes came to rest in the Yale University library. ${ }^{2}$

Recently another case-North Carolina versus B. C. West, Jr., an autograph dealer-has troubled the waters once again. Perhaps before the ripples it has occasioned become waves, the perspectives of the different specialists involved in the field could be more thoroughly aired. The present paper is a brief attempt by a public archivist to present his point of view (and that of his institution) on the replevin issue.

\section{RECENT DEVELOPMENTS}

The last few years have witnessed a remarkable change both in the public awareness of the importance of archives and in the questions of the ownership of, and access to, the records and papers created by public officials. In 1977 three events took place that reflected the new public awareness and the growing belief that the public interest in records created by government officials is paramount to private interests.

The B. C. West case is, of course, the most noted of those events. Its details, involving the ownership of several preRevolutionary court documents, need not be narrated here ${ }^{3}$ What is important is that the North Carolina Supreme Court concluded that the public sovereignty over the records in question had not lapsed since the 
eighteenth century. No disposal authority had been given by the legislature, and thus the records rightfully belonged to the state.

The second event revolves around the telephone transcripts Henry Kissinger created while he was secretary of state. Early in 1977, after Kissinger donated his papers to the Library of Congress, a group of scholars, journalists, and others sued in the federal district court to have the telephone transcripts returned to the custody of the federal government. They argued that the transcripts were records produced by government officials and that most of the transcripts involved the public business being done by Kissinger.

In his decision of December 8, 1977, Judge John Lewis Smith, Jr., agreed with the plaintiffs: "The records in dispute here," he wrote, "were produced not only in accordance with department regulations, but also on Government time and with the aid of department employees, equipment, materials and other public resources. Having been prepared and transcribed in the discharge of his official duties, the notes are the property of the United States." 4 That decision has been appealed to the U.S. Court of Appeals. For the present, however, it represents a judicial view that is very decidedly on the side of the public's interest.

The report of the "Public Documents Commission," completed in March 1977, also directed its study and recommendations to the public's right to know as a primary consideration for new legislation to control the disposition of the papers of members of Congress, the president, and the federal judiciary. Although the members of the commission did not agree in all matters, there was basic agreement that (as the majority report put it) "all documentary materials made or received by Federal officials in connection with their constitutional and statutory duties should be the property of the United States."5

Since Watergate and the Nixon papers cases, most of the publicity and interest has been directed to presidential papers, but the trend toward the public ownership of papers created by all public officials in carrying out their official duties is widely accepted as improving the operation of the government and assuring the fullest possible reconstruction of our national history.

In short, the last several years have witnessed a significant thrust in the direction of enlarging the area of public records and public control over the documentary evidence of doing the public's business.

\section{The Nature OF ARCHIVES}

This was not always the case. The nineteenth century did not have the same concern for the preservation of public records, and the private collectors and publishers of federal and state government records were, in many cases, vital to the ultimate preservation of many public documents. That role was the consequence of a number of factors. Some people in the nineteenth century, including Thomas Jefferson, thought all important records, those that were historically valuable, could be printed in multiple sets of volumes.

Moreover, the United States was very slow in establishing archival repositories to preserve. government records. Not until the twentieth century did states and the federal government pass adequate laws for archival authorities and provide sufficient funds for the safe retention of permanently valuable records in public archives.

The disregard for necessary archival agencies in the nineteenth century has now been reversed. State archival authorities were begun in the first decade of this century, the National Archives was established in 1934, and now all fifty states have a state archives, even if a few are still less than completely effective. ${ }^{6}$

The expansion in numbers and services of archival institutions in recent years includes many municipalities, businesses, and university archives, as well as manuscript collections located in university and college libraries or in historical societies. These institutions are now responsible for preserving the public records and making those records available for public use, and availability includes not only scholars but the many people now seeking evidence of their own families' and their own localities' histories.

The archives and institutional collections that are now established have taken the place of the private collector as the major agent for the preservation of our documentary heritage. Operating with adequate se- 
curity measures, these institutions collect, describe, and make available the documentation of our past.

As public awareness of and insistence on the preservation and access to all types of records has grown, the role of the private collector has diminished, and the role of what we might term the institutional collector has greatly increased. In this process public archivists, librarians, and manuscript curators have joined forces to preserve the heritage of the past. But it would be dangerous to ignore differences between professional perspectives of public archivists on the one hand and those of manuscript curators and perhaps librarians on the other.

The public archives movement was the child of what the historian Robert Palmer has aptly called the "age of democratic revolution."7 The pioneer in America was Charles Thomson, secretary of the Continental Congress and careful preserver of its records (which are now in the National Archives). But it was, in fact, the French Revolution that created the pioneer of modern public archival institutions.

The Archives Nationales was established in 1790 as the first national archival institution and was given broad authority to preserve the records of the Old Regime and the new society being built in France. From the experience of the French archivists in the next decades came the principle of $r e$ spect des fonds, or (as it is usually put in English) the principle of provenance. This is the guiding principle for the organization and handling of archives, be they public archives or the formal archives of a business, a church, or a university. ${ }^{8}$

Put quite simply, the principle of provenance means that the original order and integrity of records should be retained, since that order provides information about the men and women who created the records and their activities that goes well beyond the informational content of the individual documents. The relationships between the records can, thus, tell us something that the individual records cannot. They can, for example, reflect the decision-making process and not just the decisions themselves. Archives, then, have an organic character, and like anything organic they suffer when their integrity is disturbed.
The map carefully preserved in the records of an exploring expedition has greater meaning than the same map separated from those records and made part of a collection of maps, and the records of the expedition would be the poorer for its loss. The lawyer's letter seeking more time to develop a brief might have some autograph value to a collector. In its proper place among the official records of Muller v. Oregon, it is part of the fascinating story of Louis Brandeis' famous and influential sociological brief of 1908. The story is incomplete without it. If that letter became an archival estray, separated from the Supreme Court file, a small but important part of Supreme Court history would be lost.

Researchers look to the archival bodies they know should have materials for their research. The organic nature of the file is destroyed, and the historical record is in fact smaller, if the researcher does not know or cannot find the entire documentation.

\section{ARCHIVAL SECURITY}

The organic character of archival materials and the loss to our national heritage are also concerns of archivists when they encounter thefts from manuscript collections and archives. Greater security measures and the increasing public awareness of the importance of historical materials has not yet lessened the number of thefts in recent years. The Society of American Archivists began a security program to document thefts and publicize means of preventing them through a newsletter and handbook. ${ }^{8}$

But the thefts are continuing. The most recent cases in California, Texas, and Virginia do not give reason to believe that collections are yet safe. And the overwhelming number of thieves who are caught acknowledge that their actions were taken simply to make money-not to preserve documents or to personally own historic manuscripts. Such thefts cannot be condoned, even by the passage of time or the fact that documents known or strongly believed to have been purloined have come to rest in a reputable repository.

Replevin provides us with one small, but necessary, tool to discourage such archival thefts. It allows those who have been wrongfully deprived of their property to 
seek its return. In our profession that property is archival materials and manuscripts, and all of us retain the simple right to replevin alienated property in the courts. Replevin actions have been used since the earliest English courts and are today part of the common law.

Statutory laws in many states and in the federal government on the alienation of government property are more important in the prosecution and recovery of thefts, whether they are manuscripts or jeeps. However, private citizens as well as governments retain the common law right to replevin property. The public interest would not be served by the elimination of that right.

Replevin actions for public archival estrays sustain a historical view and belief that official records belong to the people as represented by their governments. Archives are universally recognized as an essential part of the heritage of every community. They are indispensable in the development of national and local awareness and identity, and they constitute a basic part of the cultural property of governments and peoples throughout the world. At the same time it must be recognized that archives have an official and legal status different from that of most cultural properties.

Archives that were originally created to accomplish administrative transactions also serve as evidence of those transactions. Both as evidence and because of the information they contain, they are indispensable for the continuing administration within governments. They not only document the experience of the people, but they also record and safeguard the rights and interests of governments and individual citizens.

Archives thus constitute evidence that is essential to the continuing functions incumbent on public authorities, and they should, consequently, be in the public domain. As public property they should not be a part of private commerce and enrichment. The concern voiced by some Americans over the profits made by former government officials in writing and publishing their experiences strongly suggests the belief that public activities, and the documents that record them, belong to the public and should not be used indiscriminately for private gain.

\section{The PUblic ARChivist AND REPLEVIN}

With these many considerations in mind, perhaps a public archivist's observations on the current replevin debate are in order.

Replevin has rarely been used in the past to recover records, and there is no evidence that replevin actions are going to flood the courts in the wake of the B. C. West case. Litigation is expensive and terribly timeconsuming, and the National Archives, at least, does not eagerly seek actions in the courts. In recent years the cases surrounding the Nixon papers, the Warren Commission records, and other matters have kept federal archivists busy enough with the law and the courts. The National Archives would attempt recovery actions in court only under the most critical circumstances.

But the National Archives and other public archives should not be asked to surrender the basic right to have public government records returned to the rightful repository. If they are in fact public records, they belong to the public, and public archivists have a responsibility to ensure the preservation and availability of those public records. Nor should public archivists and archival institutions be asked to proclaim they will not exercise the right of replevin. They may promise restraint and use replevin only in the most important cases, but the statutory missions of most public archives require them to preserve the public record; and if public archives were to renounce all discretion in the use of replevin, they would be negligent in their responsibilities.

In practice, what would the National Archives position be when faced with the decision on recovery of federal records?

First, it would approach recovery actions on a case-by-case basis. There is no blanket policy that affects all replevin actions. The archives of the United States is a vast and varied body of records, and to attempt to establish a single policy for replevin of federal records would be impracticable.

In addition, decisions on a replevin action would include a number of considerations about the state of the records at that time. If the material is in a good location and likely to stay there, under professional archival control and adequately protected 
from the hazards of time, disaster, and theft, the National Archives would be inclined to leave the records in place.

The consideration for professional archival control would necessarily have to include the description and availability of the records. The materials should be available to the public and to scholarly researchers on approximately the same basis as they would be if they were in the National Archives. The National Archives is adamantly opposed to privileged access, and a decision to allow records to remain in their present status would surely include consideration of that issue. Public records must be available on an equal basis.

Two other aspects of the access question that are important to the National Archives are the description and publication of the fact that the records do exist. If the materials are unknown to the public and the scholarly community, they are in fact lost, or unavailable for use. Institutional guides and finding aids are essential to all repositories and their users. The National Archives expects public records outside its custody to be described and made known. Access should include making a reasonable number of copies at reasonable costs for re- searchers, as is done at the National Archives.

A final circumstance in a decision to begin recovery actions would be the importance of the document or documents as evidence of the activities, decisions, and policies in the federal government. The $\mathrm{Na}$ tional Archives is not likely to replevin routine documentation whose only value is an autograph. The informational content must be of consequence and value to the historical record of our past. The copy of the Declaration of Independence used by the printer Dunlap on the night of July 4, 1776 , would be in that category, and the National Archives would probably try to obtain it. A bill of lading signed by General Grant will not engender the same interest.

The importance of the material, its availability, and its security-these are the three basic criteria that the National Archives would use in making a decision on whether or not to seek legal action to recover estrays from the corpus of federal archives. They are to some degree subjective criteria, of course, but they are also the criteria set forth by the National Archives at the time of the Lewis and Clark case. Nothing that has happened in recent years suggests that there is any need for change.

\section{REFERENCES}

1. 77 C.J.S. (Corpus Juris Secundum), "Replevin," par. 4 (1952).

2. The best summary of the Lewis and Clark case is Calvin Tompkins, "Annals of the Law: The Lewis and Clark Case," The New Yorker 42:105-48 (Oct. 29, 1966).

3. William S. Price, Jr., "N.C. v B.C. West, Jr.," The American Archivist 41:21-24 (Jan. 1978), supplies a succinct summary of the case. See also Mattie Russell, "N.C. Ruling Menaces Manuscript Collections," American Libraries 8:471-72 (Oct. 1977).

4. Reporters' Committee for the Freedom of the Press, et al. v. Vance, et al.; Military Audit Project v. Department of State, et al. 442 F. Supp. 383 (D.D.C. 1977).

5. Final Report of the National Study Commission on Records and Documents of Federal Officials, March 31, 1977, p.1. The "alternate" (or minority) report concluded that "it is time to end the fiction that the public's records belong to presidents or other federal officials and therefore recognize and declare the fact that governmental records and documents belong to the people of the United States." (Ibid., p.65)

6. Basic information about the state archives can be found in John M. Kinney, comp., Directory of State and Provincial Archives, 1975 (Austin: Society of American Archivists and Texas State Archives, 1975).

7. Robert R. Palmer, The Age of Democratic Revolution, 2v. (Princeton: Princeton Univ. Pr., 1959-64).

8. A good (though slightly dated) introduction to archival theory and practice is Theodore $\mathbf{R}$. Schellenberg, Modern Archives: Principles and Techniques (Chicago: Univ. of Chicago Pr., 1956). Frank B. Evans, comp., Modern Archives and Manuscripts: A Select Bibliography (Chicago: Society of American Archivists, 1975), provides an extensive organized listing of archival literature.

9. The Archival Security Newsletter is published as a part of the SAA Newsletter. See also Timothy Walch, Archives \& Manuscripts: Security (Chicago: Society of American Archivists, 1977). 